\title{
Pendekatan Klinis Berbagai Kasus Neurologi Anak yang Membutuhkan Pemeriksan Pencitraan
}

\author{
Irawan Mangunatmadja
}

Kelainan saraf pada bayi dan anak relatif sering ditemukan, hampir $20-30 \%$ pasien rawat inap maupun rawat jalan merupakan kasus neurologis. ${ }^{1}$ Pada umumnya anak dibawa oleh orang tua berobat akibat gangguan fungsional yang dialaminya, gangguan perkembangan, gangguan kesadaran, kelumpuhan ekstremitas, kelumpuhan saraf otak, kejang dan lain-lain. Anamnesis terarah tentang riwayat penyakit, perkembangan, pemeriksaan fisis pediatrik, pemeriksaan neurologik yang teliti akan sangat membantu menentukan diagnosis fungsional, gangguan anatomik, dan perkiraan etiologik kelainan saraf yang dihadapi. ${ }^{1}$ Untuk menegakkan diagnosis pasti diperlukan pemeriksaan penunjang paling sederhana sampai yang paling canggih, seperti transiluminasi kepala, pemeriksaan darah tepi, cairan serebrospinalis, elektroneurofisiologi (elektroensefalografi, potensial cetusan, dan elektromiografi), pemeriksaan pencitraan, patologi anatomi dan lain-lainnya. ${ }^{1}$

Kata kunci: ultrasonografi, computed tomography scanning, magnetic resonance imaging

\section{Indikasi umum pencitraan dalam bidang neurologi anak}

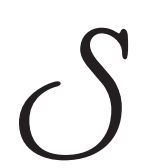

ecara garis besar kelumpuhan susunan saraf terbagi atas dua kelompok kelumpuhan yaitu (1) tipe upper motor neuron (susunan saraf pusat) dan (2) tipe lower motor neuron (susunan saraf tepi). Susunan saraf pusat dimulai dari otak $\rightarrow$ batang otak $\rightarrow$ medula spinalis $\rightarrow$ kornu anterior medula spinalis. Susunan saraf tepi dimulai dari kornu anterior medula spinalis $\rightarrow$ saraf tepi $\rightarrow$ neuromuscular junction $\rightarrow$ otot. Adapun gejala kelumpuhan tipe upper motor neuron adalah hipertoni atau spastis, refleks fisiologis meningkat, adanya refleks patologis, tanpa fasikulasi dan atrofi otot. ${ }^{2}$

Pemeriksan penunjang pencitraan diperlukan pada gangguan yang bersifat upper motor neuron dengan manifestasi klinis kelumpuhan pada ekstremitas disertai

\footnotetext{
Alamat korespondensi:

Dr. H. Irawan Mangunatmadja, Sp.A(K).

Staf Subbagian Neurologi. Bagian Ilmu Kesehatan Anak FKUI-RSCM, Jl. Salemba 6, Jakarta 10430.

Telpon: 021-3149161, Fax.: 021-3907743.
}

kelumpuhan saraf kranialis, maka kelainan diduga pada daerah otak dan batang otak. Apabila kelumpuhan hanya mengenai ekstremitas saja maka diduga kelainan terletak pada daerah medula spinalis.

Pemeriksaan pencitraan meliputi foto polos kepala atau tulang belakang, ultrasonografi (USG) kepala, computed tomography scanning (CT scan) dan magnetic resonance imaging (MRI). Kemampuan memvisualisasikan jaringan otak secara langsung dengan USG, CT scan, dan MRI telah meningkatkan kemampuan diagnostik ahli saraf anak. ${ }^{1}$

Pemeriksaan foto polos kepala dan tulang belakang penggunaannya terbatas untuk mendeteksi dan mengevaluasi beberapa anomali kongenital, peninggian tekanan intrakranial serta trauma kepala dan spinal. ${ }^{1}$ USG kepala dapat digunakan untuk evaluasi ensefalopati hipoksik iskemik meliputi komplikasi perdarahan pada matrik germinal, ventrikel, atau parenkim otak; skrining malformasi developmental, mengetahui penyebab pembesaran kepala, leukomalasi periventrikular, resorpsi perdarahan, porensefali, 
sindrom Dandy-Walker dan lain-lain. ${ }^{3}$

Pemeriksaan $C T$ scan lebih ditujukan untuk mendeteksi adanya kelainan yang bersifat akut, kalsifikasi intrakranial dan komplikasi pasca operasi, edemotak, infark, neoplasma, leukodistrofi, dan lainlain. ${ }^{3}$ Adapun MRI mempunyai kelebihan antara lain dalam hal mendeteksi adanya lesi, lokalisasi lesi lebih akurat, gangguan fungsi pada daerah otak dibandingkan USG dan CT scan, mesial temporal sklerosis, konseling genetik dapat digabung dengan PET (positron emission tomography) scan atau magnetic resonance spectroscopy (MRS)..$^{1,3}$

\section{Kelainan neurologi anak yang memer- lukan pemeriksaan pencitraan}

\section{Gangguan perkembangan}

Pasien dengan gangguan perkembangan dapat datang dengan keluhan keterlambatan perkembangan atau malformasi kongenital. Umumnya mereka datang pada umur sebelum 1 tahun. Pada perkembangan terlambat didapatkan lingkaran kepala kecil, fontanel anterior lebar atau menyempit, gangguan penglihatan, ekstremitas spastis, dengan refleks meningkat. Bila pada riwayat kehamilan didapatkan infeksi $T O R C H$, maka pencitraan $C T$ scan kepala adalah pilihan pertama. Pada CT scan kepala dapat ditemukan atrofi otak dan kalsifikasi intrakranial (Gambar 1).4,5

Pada MRI dan CT scan kepala dapat terdeteksi

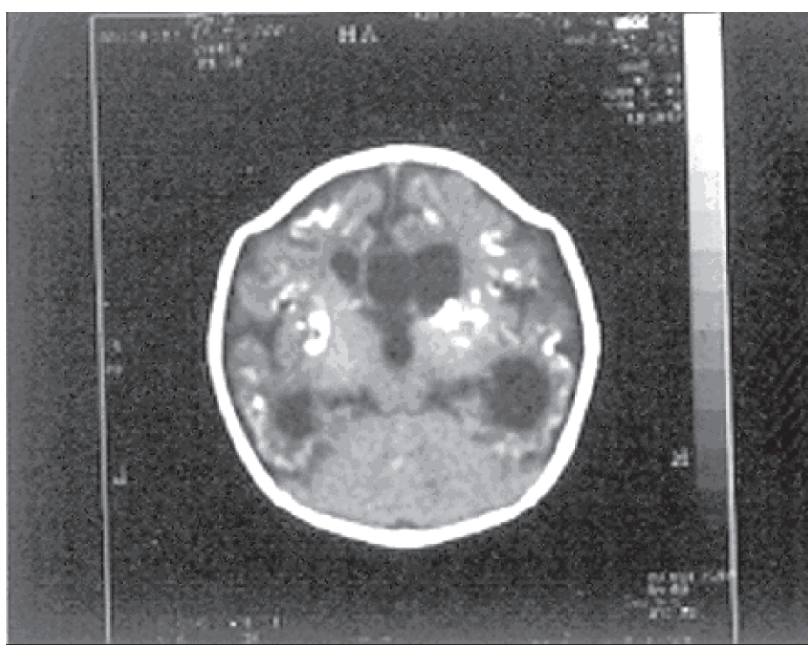

Gambar 1. Kalsifikasi intrakranial pada infeksi toksoplasmosis kongenital adanya defek migrasi neuron seperti lisensefali, holoprosensefali atau agenesis korpus kalosum. MRI dapat mendeteksi polimikrogria dan heterotopia ringan yang tak terdeteksi oleh CT scan ${ }^{6}$

Pada malformasi kongenital dapat ditemukan mielomeningokel daerah lumbal yang akan menyebabkan gangguan pada tungkai bawah, sedangkan daerah sakral akan menyebabkan gangguan pada lutut dan pergelangan kaki. ${ }^{7}$ Pemeriksaan MRI dapat mendeteksi jenis defek yang terjadi dan lokasinya.

Pada hidrosefalus didapatkan tanda klinis berupa ukuran kepala di atas 2 deviasi standar, fontanel anterior yang membonjol, tonus leher - bahu dan batang tubuh yang lemah, gangguan penglihatan, serta adanya refleks ekstremitas yang meningkat. Pada $C T$ scan kepala dapat terdeteksi adanya gambaran hidrosefalus disertai daerah sumbatan. Pada MRI akan mudah terdeteksi Malformasi Arnold Chiari atau sindrom Dandy Walker yang mungkin tak terdeteksi dengan CT scan. malformasi Arnold Chiari ditandai dengan elongasi dan protusi serebelum melalui foramen magnum ke arah medula spinalis servikal. Pada Sindrom Dandy Walker terdapat agenesis vermis serebelum, dilatasi ventrikel IV dan pelebaran fosa posterior. ${ }^{6,7}$

\section{Perdarahan intrakranial}

Kecurigaan adanya perdarahan intrakranial pada neonatus difikirkan bila dijumpai adanya riwayat prematuritas, persalinan dengan alat (vakum atau forsep), adanya kejang fokal. Pada pemeriksaan fisis neurologik didapatkan kesadaran menurun, jejas vakum atau forsep, fontanel anterior yang membonjol, perdarahan subhialoid pada retina, pucat, refleks ekstremitas yang meningkat dan atau hemiparesis.

Bila pada bayi berusia 1-3 bulan ditemukan manifestasi klinis, berupa pucat, kejang fokal, kesadaran menurun, fontanel anterior yang membonjol, perdarahan subhialoid retina dan/atau hemiparesis perlu dicurigai adanya perdarahan intrakranial yang disebabkan oleh adanya defisiensi kompleks protrombin didapat sebagai akibat kekurangan vitamin K (Gambar 2).

a Pada anak yang lebih besar, ubun-ubun sudah menutup dengan riwayat trauma kepala, penyakit darah, muntah berlebihan, kejang fokal atau umum, pucat, jejas trauma di kepala, kesadaran menurun, papiledem atau perdarahan subhialoid retina, dan hemiparesis dianjurkan pemeriksaan CT scan kepala. 


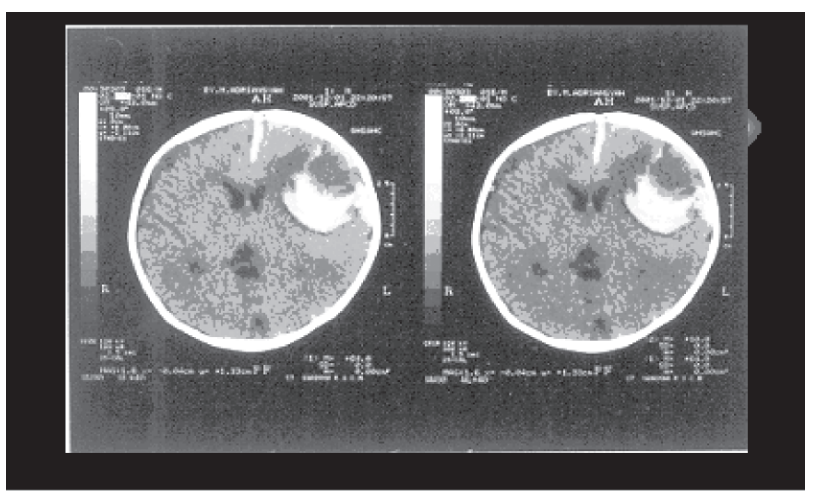

Gambar 2. Perdarahan intrakranial akibat defisiensi vitamin $\mathrm{K}$

b. Pada keadaan ubun-ubun besar belum menutup dapat dilakukan pemeriksaan USG kepala. Sedangkan pada prematuritas dengan masa gestasi kurang dari 32 minggu atau berat lahir kurang dari 1500 gram, dianjurkan pemeriksaan USG kepala dalam 7 hari pertama kehidupan untuk mendeteksi adanya perdarahan intrakranial. ${ }^{1} C T$ scan merupakan pemeriksan penyaring terpilih pada anak dengan perdarahan intrakranial akut (kurang dari 2 minggu), sedangkan MRI lebih sensitif untuk perdarahan yang bersifat subakut maupun kronik. ${ }^{9}$

\section{Proses desak ruang pada susunan saraf pusat}

Adanya proses desak ruang perlu dipikirkan bila didapatkan gejala peningkatan tekanan intrakranial riwayat keluhan pusing, muntah yang telah berlangsung lama, penurunan kesadaran, dilatasi pupil, kejang fokal atau umum, dan edem papil. Demam yang berlangsung lama dicurigai ke arah abses otak, sedang tak adanya demam dicurigai ke arah tumor. Berdasarkan letaknya di bagi atas supratentorial dan infratentorial.

Proses desak ruang pada daerah supratentorial akan memberikan gejala berupa kelemahan wajah, lengan dan tungkai, disfasia, perubahan kepribadian (lobus frontalis); gangguan lapang pandang (lobus oksipitalis); disfasia reseptif, gangguan lapang pandang (lobus temporalis); apraksia, buta huruf (daerah korpus kalosum); gangguan sensasi, lapang pandang, kebingungan kiri atau kanan, sensori atau motorik (lobus parietalis); gangguan endokrin (kelenjar hipotalamus atau hipopituari). ${ }^{10}$ Proses desak ruang pada daerah infratentorial akan memperlihatkan gejala paresis saraf kranialis III - XII, gangguan motorik dan sensorik, gerak bola mata, penurunan kesadaran, tremor, dilatasi pupil (daerah batang otak); jalan ataksik, tremor intensi, dismetri, disartri dan nistagmus (daerah serebelum). ${ }^{10}$

Pencitraan terpilih adalah $C T$ scan atau MRI kepala. CT scan diindikasikan terutama pada kecurigaan lesi daerah supratentorial, sedangkan MRI sangat terindikasi bila ada kecurigaan lesi daerah infratentorial - batang otak (Gambar 3a dan 3b). Pada keduanya dapat terlihat adanya gejala desak ruang yaitu pergeseran garis tengah, kompresi ventrikel dan

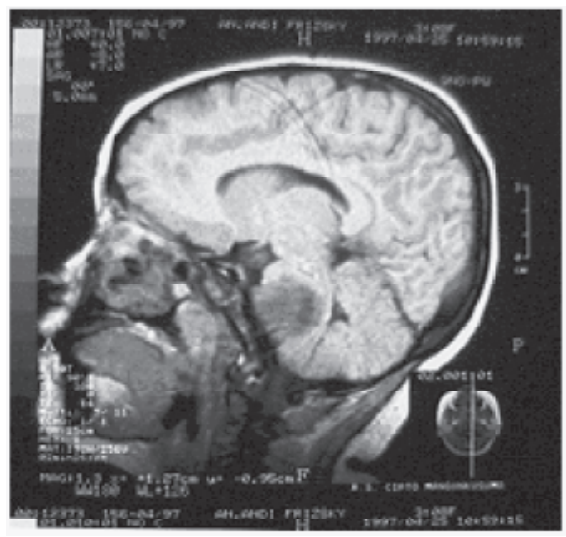

Gambar 3a. Tumor batang otak tanpa kontras

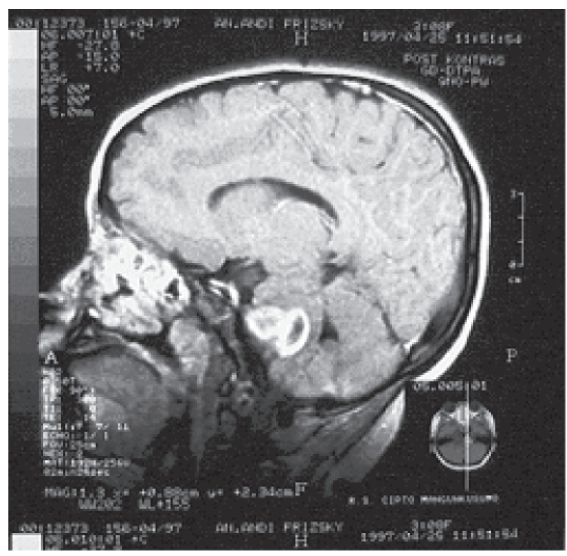

Gambar 3b. Tumor batang otak dengan kontras

hidrosefalus. Masa soliter atau multipel yang sering dikelilingi edema perifokal (Gambar 4). ${ }^{10}$

Proses desak ruang pada daerah vertebra ditandai dengan adanya gejala upper motor neuron pada ekstremitas. Kelumpuhan yang mengenai lengan dan 


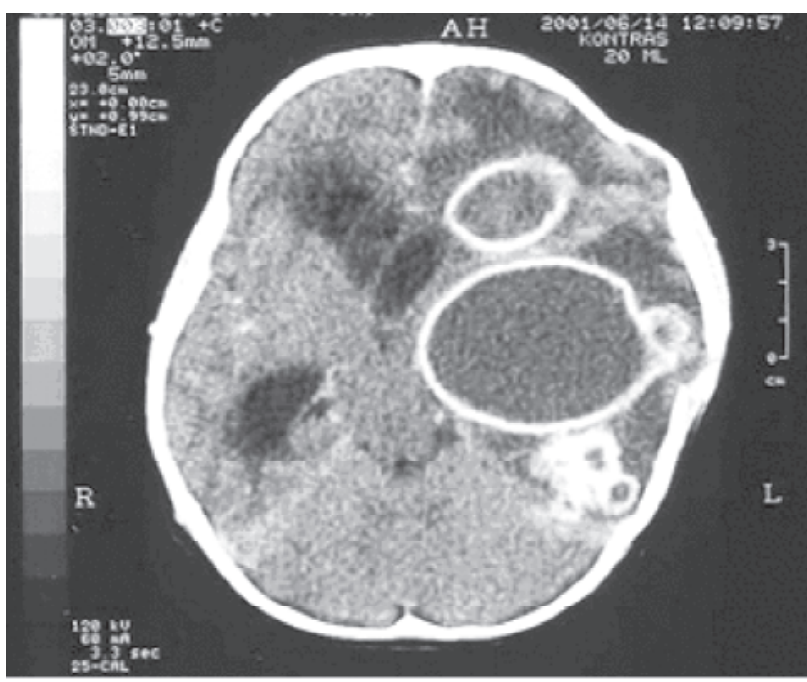

Gambar 4. Abses serebri multipel dengan kontras

tungkai menunjukkan lokasi setinggi vertebra servikotorakal. Kelumpuhan yang hanya mengenai tungkai menunjukkan lokasi setinggi vertebra lumbo sakral. Lesi intraspinal dapat diperlihatkan dengan baik dengan pemeriksaan $C T$ scan mielografi atau MRI vertebra. ${ }^{2}$

\section{Penyakit vaskular}

Gangguan vaskular pembuluh darah otak perlu dicurigai, bila dijumpai gejala pusing progresif pada lokasi tertentu, muntah, kejang fokal atau umum serta kelumpuhan lengan yang lebih menonjol dibanding tungkai, atau adanya riwayat kelainan jantung bawaan. Umumnya dapat terjadi pada oklusi, dan emboli pembuluh darah otak tertentu. Bila selain gejala di atas, ditemukan pula pusing yang hebat, perdarahan otak, kuduk kaku atau bila terdapat cranial bruit pada daerah bola mata, maka lebih dicurigai ke arah adanya malformasi ateriovena. ${ }^{11}$

Pemeriksaan yang dianjurkan adalah CT scan, atau MRI dan angiografi kepala. Saat ini MRI telah menjadi pemeriksaan penyaring arteriovena malformasi karena mudah mendeteksi dan melokalisasinya. ${ }^{11,12}$ CT scan dan MRI kepala di atas 24 jam setelah terjadinya stroke akut memperlihatkan gambaran infark pada daerah yang terkena. MRI lebih sensitif dibandingkan CT scan dalam mendeteksi infark yang kecil dan multipel. ${ }^{13}$

\section{Infeksi susunan saraf pusat}

Kecurigaan kearah infeksi susunan saraf pusat pada bayi dan anak bila dijumpai gejala demam tinggi akut maupun kronis, muntah, pusing (anak usia lebih 3 tahun), kejang, penurunan kesadaran, fontanel anterior membonjol, dengan atau tanpa gejala rangsang meningeal, paresis motorik maupun saraf kranialis. Berdasarkan riwayat penyakit, pemeriksaan neurologis dan hasil analisa cairan serebrospinalis, infeksi susunan saraf pusat dibedakan atas ensefalitis, meningitis bakterialis, meningitis serosa virus dan meningitis serosa tuberkulosa.

Pada pasien meningitis bakterialis, serosa tuberkulosa bila dalam pengobatan demam tidak turun dan klinis tidak ada perubahan perlu difikirkan adanya komplikasi dari penyakit tersebut. Komplikasi dapat disebabkan antara lain oleh efusi subdural, hidrosefalus, abses otak atau ventrikulitis. Komplikasi efusi subdural dapat ditemukan pada pengobatan meningitis bakterialis (Gambar 5).

Pemeriksaan pencitraan tidak dilakukan secara rutin dan hanya terindikasi bila terdapat ketidakjelasan diagnosis, perburukan gejala neurologik akibat peningkatan tekanan intrakranial, panas berkepanjangan, kejang berulang, kelainan neurologik fokal, proses penyembuhan yang lambat atau untuk mendeteksi komplikasi lainnnya. ${ }^{5,14}$ Pada ensefalitis herpes simpleks, MRI lebih sensitif dibandingkan $C T$ scan dalam menunjukkan kelainan lobus medio temporal, daerah orbitofrontal, atau daerah girus singuli. ${ }^{15}$ Pada meningitis bakterialis

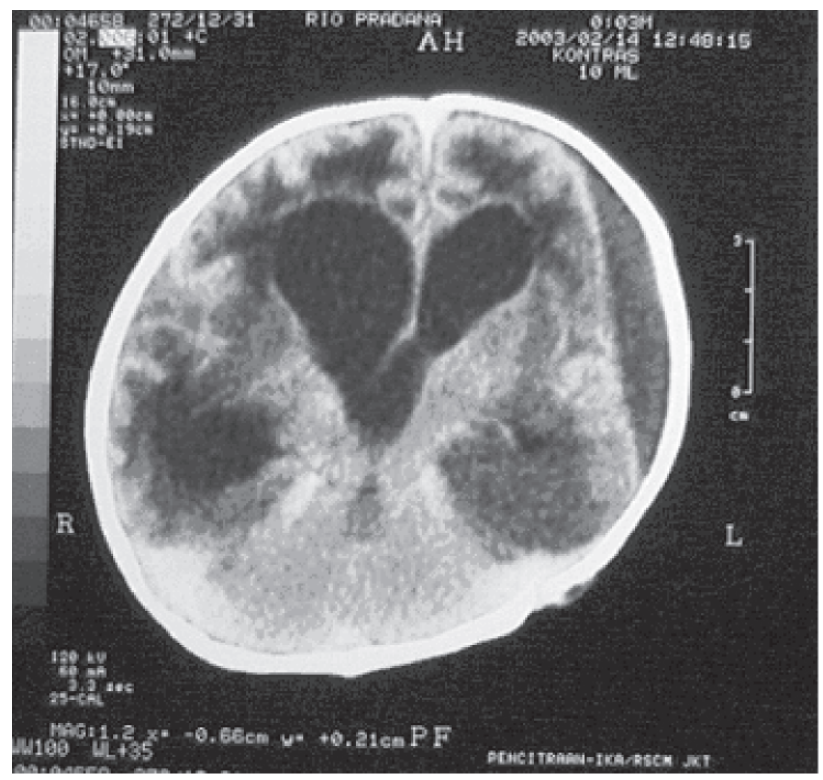

Gambar 5. Efusi subdural pada pasien meningitis bakterialis 
pada MRI atau CT scan didapatkan gambaran edem, ventrikulomegali, hidrosefalus, pelebaran ruang subaraknoid, infark atau efusi subdural. ${ }^{5,14}$ Ventrikulitis pada neonatus dan bayi dapat dideteksi dengan USG dan CT scan kepala. CT scan dan MRI pada meningitis tuberkulosis terutama menunjukkan kelainan pada daerah basal otak, hidrosefalus,lesi parenkim, infark dan tuberkuloma. CT scan dan MRI spinal terindikasi pada anak dengan gejala neurologis yang diduga disebabkan oleh tuberkulosis spinal. $^{5}$

\section{Penyakit neurokutan}

Penyakit neurokutan dapat dibagi atas neurofibromatosis - von Recklinghause disease (NF), tubero sclerosis (TS), ataksia teleangiektasi (TA), sindrom Sturge-Weber (SSW). Kecurigaan didasarkan adanya gejala café au lait spot (lebih dari $15 \mathrm{~mm}$, berjumlah lebih dari 6 buah) kejang fokal atau umum, nodul kutan ( neurofibromatosis); ataksia serebelar, koreoatetosis, teleangiektasis pembuluh darah mata atau kulit (TA); port wine nevus pada bagian atas wajah, kemunduran neurologis, perkembangan terlambat (SSW). ${ }^{16}$

Pada CT scan dan MRI kepala didapatkan gambaran tumor intrakranial - glioma optik atau tumor intraspinal (NF); subependimal hamartoma tuber (TS); kalsifikasi posterior (SSW) ${ }^{16}$

\section{Epilepsi}

Pada pasien epilepsi pemeriksaan pencitraan yang diperlukan adalah CT scan, MRI dan PET scan. Tidak semua pasien dengan kejang harus menjalani pemeriksaan pencitraan. Epilepsi umum idiopatik dengan neurologis normal, sangat jarang memperlihatkan kelainan pada pencitraan. Pemeriksaan pencitraan hanya terindikasi pada keadaan dengan kelainan neurologik termasuk wajah dismorfik, kejang fokal disertai kelainan EEG fokal, kecurigaan adanya malformasi kongenital di korteks, heterotopia massa kelabu, dan epilepsi intraktabel. ${ }^{17-18}$ MRI adalah pilihan utama pencitraan pada epilepsi. Magnetic Resonant Imaging dapat mendeteksi adanya mesial temporal sclerosis. Pemeriksaan MRI disertai PET scan ditujukan pada pasien dengan epilepsi fokal yang menjadi umum, yang akan menjalani bedah epilepsi. ${ }^{17}$

\section{Lain-lain}

\section{a. Ensefalopati hipoksik iskemik}

Diagnosis ini ditegakkan pada bayi baru lahir berdasarkan adanya riwayat asfiksia intrauterin atau insufisiensi respirasi pasca natal. Pada pemeriksaan neurologis didapatkan penurunan kesadaran, kebiruan, jittery, dan kelemahan pada ekstremitas atas. Pemeriksaan pencitraan $C T$ scan memperlihatkan gangguan difus neuron korteks. Ultrasonografi memperlihatkan fokal atau multifokal lesi iskemik otak. Sedangkan MRI memperlihatkan meningkatnya signal pada daerah perirolandik korteks, basal ganglia disertai menurunnya intensitas signal pada periventrikular masa putih dan kapsul interna. ${ }^{19,20}$ Pencitraan pada usia 3 bulan memperlihatkan luas kerusakan yang terjadi. ${ }^{20}$

\section{b. Nyeri kepala}

Seringkali dipertanyakan apakah nyeri kepala memerlukan pemeriksaan pencitraan. Pada keadaan nyeri kepala kronis tanpa gejala neurologik progresif atau peningkatan tekanan intrakranial, maka pencitraan dapat ditunda. Pencitraan CT scan atau MRI dianjurkan pada pasien dengan adanya gejala neurologik fokal atau kekhawatiran yang berlebihan dari orangtua pasien. ${ }^{21}$

\section{c. Kelainan gerak}

Kelainan gerak meliputi korea, atetosis, distonia, mioklonus, tremor, tick dan balismus, yang disebabkan gangguan pada daerah basal ganglia. Pencitraan $C T$ scan atau MRI kepala dapat memperlihatkan adanya atrofi nukleus kaudatus. ${ }^{22}$

\section{Kesimpulan}

Berdasarkan uraian di atas dapat disimpulkan bahwa pemilihan jenis pencitraan yang diperlukan untuk menunjang diagnosis penyakit susunan saraf pada anak didasarkan atas anamnesis riwayat penyakit, perkembangan, pemeriksaan fisis pediatrik, pemeriksaan neurologik dan laboratorium penunjang. Beberapa hal yang perlu ditentukan adalah jenis pencitraan, daerah yang diperiksa, waktu pemeriksaan, serta kemungkinan hasil yang diharapkan. Diharapkan dengan adanya 
pertimbangan di atas, hasil pencitraan dapat digunakan untuk menunjang diagnosis dan tata laksana pasien sebaik-baiknya, walaupun hasil pencitraan kadangkala hanya berguna untuk menyingkirkan diagnosis banding atau komplikasi yang terjadi pada pasien.

\section{Daftar pustaka}

1. Ismael S, Passat J. Gambaran umum penyakit saraf pada usia bayi dan anak yang memerlukan pemeriksaan pencitraan. Dalam: Nurhamzah W, Pramulyo HS, Andayani P, penyunting. Pencitraan: penggunaannya untuk menunjang diagnosis penyakit saluran napas dan saraf pada anak. Naskah lengkap Pendidikan Kedokteran Berkelanjutan Ilmu Kesehatan Anak XL Jakarta: Balai Penerbit FKUI, 1997. h. 1-12.

2. Lindsay KW, Bone I. Neurology and neurosurgery illustrated. Edisi ketiga ed. New York: Churchill Livingstone, 1997. h. 189-94.

3. Wycliffe ND, Thompson JR, McLeary M, Holshouser BA, Ashwal S. Pediatric neuroimaging. Dalam: Swaiman KF, Ashwal S, penyunting. Pediatric neurology principles and practice, Edisi ketiga ed. St Louis: Mosby, 1999. h. 122-41.

4. Barkovich AJ. Pediatric neuroimaging, Edisi kedua. New York: Raven Pres, 1995. h. 569-617.

5. Weil ML, Tuomanen E, Israele V, Rust R, Menkes JH. Infections of the nervous system. Dalam: Menkes JH, Sarnat HB, penyunting. Child Neurology, edisi keenam. Philadelphia: Lippincott Williams \& Wilkins, 2000. h. 467-626.

6. Barkovich AJ. Pediatric neuroimaging. 2nd edition, New York: Raven Pres, 1995. h. 177-275.

7. Menkes JH, Sarnat HB. Malformations of the central nervous system. Dalam: Menkes JH, Sarnat HB, penyunting. Child Neurology, edisi keenam. Philadelphia: Lippincott Williams \& Wilkins, 2000. h. 305-400.

8. Casella JF, Pelidis MA. Disorders of coagulation factors. Dalam: McMillan JA, DeAngelis CD, Feigin RD, Warshaw JB, penyunting. Oski's pediatrics principles and practice, Edisi ketiga ed. Philadelphia: Lippincott Williams \& Wilkins, 1999. h. 1481-90.

9. Barkovich AJ. Pediatric neuroimaging, Edisi kedua. New
York: Raven Pres, 1995. h. 619-53.

10. Lindsay KW, Bone I. Neurology and neurosurgery illustrated. Edisi ketiga ed. New York: Churchill Livingstone, 1997. h. 293-302.

11. Lindsay KW, Bone I. Neurology and neurosurgery illustrated. Edisi ketiga ed. New York: Churchill Livingstone, 1997. h. 288-92.

12. Menkes JH, Sarnat HB. Cerebrovascular disorders. Dalam: Menkes JH, Sarnat HB, penyunting. Child Neurology, edisi keenam. Philadelphia: Lippincott Williams \& Wilkins, 2000. h. 885-917.

13. DeVeber G. Cerebrovascular disease in children. Dalam: Swaiman KF, Ashwal S, penyunting. Pediatric neurology principles and practice, Edisi ketiga ed. St Louis: Mosby, 1999. h. 1099-124.

14. Snyder RD. Bacterial infections of the nervous system. Dalam: Swaiman KF, Ashwal S, penyunting. Pediatric neurology principles and practice, Edisi ketiga ed. St Louis: Mosby, 1999. h. 981-1000.

15. Bale JF. Viral infections of the nervous system. Dalam: Swaiman KF, Ashwal S, penyunting. Pediatric neurology principles and practice, Edisi ketiga ed. St Louis: Mosby, 1999. h. 1001-24.

16. Menkes JH, Maria BL. Neurocutaneous syndromes. Dalam: Menkes JH, Sarnat HB, penyunting. Child Neurology, edisi keenam. Philadelphia: Lippincott Williams \& Wilkins, 2000. h. 859-84.

17. .Menkes JH, Sankar R. Paroxysmal disorders. Dalam: Menkes JH, Sarnat HB, penyunting. Child Neurology, edisi keenam.Philadelphia: Lippincott Williams \& Wilkins, 2000. h. 919-1026.

18. Meiners LC. Neuroimaging: tecniek en toepassiengen. Disampaikan pada Seminar Epilepsie, diagnose en behandeling, Utrecht, 13 November 2002.

19. Volpe JJ. Neurology of the newborn, edisi keempat. Philadelphia: WB Saunders Company, 2001. h. 331-94

20. Barkovich AJ. Pediatric neuroimaging. Edisi kedua, New York: Raven Pres, 1995. h. 113-42.

21. Rodner AD. Headaches. Dalam: Swaiman KF, Ashwal $S$, penyunting. Pediatric neurology principles and practice, Edisi ketiga ed. St Louis: Mosby, 1999. h. 747-72.

22. Swaiman KF. Movement disorders and disorders of the basal ganglia. Dalam: Swaiman KF, Ashwal S, penyunting. Pediatric neurology principles and practice, Edisi ketiga ed. St Louis: Mosby, 1999. h. 801-31. 